Summer 2013

\title{
Societal Constitutionalism, Social Movements, and Constitutionalism from Below
}

Gavin W. Anderson

University of Glasgow, Gavin.Anderson@glasgow.au.uk

Follow this and additional works at: https://www.repository.law.indiana.edu/ijgls

Part of the Constitutional Law Commons, International Law Commons, and the Transnational Law Commons

\section{Recommended Citation}

Anderson, Gavin W. (2013) "Societal Constitutionalism, Social Movements, and Constitutionalism from Below," Indiana Journal of Global Legal Studies: Vol. 20 : Iss. 2 , Article 11.

Available at: https://www.repository.law.indiana.edu/ijgls/vol20/iss2/11

This Symposium is brought to you for free and open access by the Law School Journals at Digital Repository @ Maurer Law. It has been accepted for inclusion in Indiana Journal of Global Legal Studies by an authorized editor of Digital Repository @ Maurer Law. For more information, please contact rvaughan@indiana.edu.

\section{$\Psi$}

JEROME HALL LAW LIBRARY

INDIANA UNIVERSITY

Maurer School of Law
Bloomington 


\title{
Societal Constitutionalism, Social Movements, and Constitutionalism from Below
}

\author{
GAVIN W. ANDERSON*
}

ABSTRACT

Within constitutional theory, in comparison to other fields of scholarship, the significance of transnational social movements has been relatively unexamined in the literature. Societal constitutionalism, grounded in the sociological method and open to reexamining received understandings of constitutionalism, would appear conducive to undertaking this enterprise. However, the general absence of social movements from the societal constitutionalism literature is not coincidental, and reflects a shared commitment with more conventional approaches to an institutional conception of constitutionalism, and a belief in the latter's necessary benevolence and Western origin. These assumptions reflect the limited focus of contemporary analyses of globalization and constitutionalism upon "globalization from above." As key protagonists within "globalization from below," social movements represent a form of "constitutionalism from below." Incorporating social movements within constitutional discourse deepens the sociological turn favored by societal constitutionalism by revealing the always-existing noninstitutional dimension of constitutionalism. Moreover, doing so locates in social movements the potential for a transformative constitutional agency which has often proven elusive.

\section{INTRODUCTION}

In the evocative title of his 2012 book on "the new global revolutions," BBC Newsnight economics editor Paul Mason asks "Why

* LL.B (Glasgow), LL.M (Osgoode Hall), S.J.D. (Toronto). Senior Lecturer, School of Law, University of Glasgow, 2001-present; previously, Lecturer, School of Law, University of Warwick 1993-2001, and Jean Monnet Fellow, European University Institute, Florence, 2003-2004. Author of CONSTITUTIONAL RIGHTS AFTER GLOBALIZATION (2005).

Indiana Journal of Global Legal Studies Vol. 20, Issue 2 (2013)

(C) Indiana University Maurer School of Law 
it's Kicking Off Everywhere."1 Focusing on recent high profile episodes of social unrest, from the Arab Spring and mass demonstrations in Tehran to the eponymous actions of the Occupy movement, Mason charts the rise of a new form of political mobilization coordinated (if such be the word) around social media and driven by technological innovation: "spontaneous horizontal[ism]"2 in place of the traditional forms of top-down organized politics. Commenting on the meaning of this global upsurge in rebellion and revolt, Mason argues that we are "in the middle of a revolution"3 where even once unassailable features of capitalism are being eroded. This revolution, he suggests, is reshaping established hierarchies, and as a consequence is "changing the balance of power between the leaders and the led." 4 Perhaps the most striking aspect of his analysis is that few in the citadels of power, whether Arab dictatorships or corporate boardrooms, saw this coming. ${ }^{5}$ Accordingly, he speculates that at the present juncture-and reversing historical trends-those at the bottom, armed with their tweets and blogs, may have the advantage of being more in tune with the times than those in authority, whose monopoly of official force often proved futile in maintaining their hold on power. ${ }^{6}$

From another perspective, these developments seem less surprising. Rather than appearing out of the clear blue, they can be seen as the latest manifestation of an emergent phenomenon described as "globalization-from-below."7 The initial scholarly reaction to globalization emphasized greater homogenization of national policies to accord with the principles of liberalization and marketization of the "Washington consensus."8 More recently, the literature has focused upon (generally Southern-based) resistance to these processes, calling into doubt the hegemonic qualities formerly attributed to them. ${ }^{9}$ Much of this latter scholarship has addressed the role played by social movements in constructing an alternative vision of globalization to neoliberalism and has generated extensive literature across a range of

1. Paul Mason, Why it's Kicking OfF Everywhere: The New Global REVOLUTIONS (2012).

2. Id. at $44-46$.

3. Id. at 3 .

4. Id. at 83 .

5. Id. at 25-39.

6. See id. at 65-66.

7. Richard Falk, Predatory Globalization: A CRitique 130 (1999).

8. For a collection of multiple articles exemplifying this reaction, see generally Globalization: CRITICAL REFleCtions (James H. Mittelman ed., 1996).

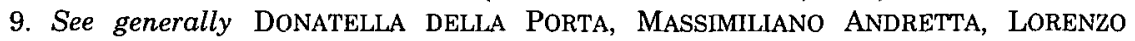
MOSCA \& HERBERT REITER, GLOBALIZATION FROM BELOW: TRANSNATIONAL ACTIVISTS AND PROTEST NETWORKS (2006). 
disciplines, including ethics, ${ }^{10}$ human rights, ${ }^{11}$ anthropology, ${ }^{12}$ international relations, ${ }^{13}$ political economy, ${ }^{14}$ political history, ${ }^{15}$ and legal sociology. ${ }^{16}$ The years 2009-2011 may in retrospect come to represent the period when what had long been documented by scholars of the global South became visible to Western eyes, not just because parts of the South itself were changing in remarkable ways, but also because "below" was no longer confined to the South and was all too present on the streets of Western capitals.

For some, addressing the significance of transnational social movements is one of the leading intellectual challenges of our time, representing "the very beginning of a rew field of study and of social action."17 Taking up this challenge, others have suggested that adverting to social movements enables us to see the ostensibly ingrained contours of established disciplines in a more fluid and potentially transformative manner. ${ }^{18}$ Underpinning these enterprises is the sense that our perceived understandings of power, including its nature, location, and how it can be challenged and remade, require reappraisal once we bring social movements directly into the frame of analysis. However, to adapt Mason's terminology, one discipline where this process of rethinking is not "kicking off" is the field of constitutional theory. While there is now an extensive literature on the constitutional implications of "top-down" global regimes, such as the World Trade Organization (WTO) ${ }^{19}$ or investment rules treaties, ${ }^{20}$ there has been very little analysis of the potential relevance of "bottom-up" phenomena of social movements. This article addresses why this is the case and what importance should be attached to this omission.

10. E.g., Simon Critchley, Infinitely Demanding: Ethics of Commitment, POLITICS OF RESISTANCE (2008).

11. E.g., Neil Stammers, Human Rights and Social Movements (2009).

12. E.g., The Practice of Human Rights: Tracking LaW Between the Global and THE LOCAL (Mark Goodale \& Sally Engle Merry eds., 2007).

13. E.g., Ronaldo Munck, Globalization and Contestation: The New Great COUNTER-MOVEMENT (2007).

14. E.g., Robert O'Brien et al., Contesting Global Governance: Multilateral ECONOMIC INSTITUTIONS AND GLOBAL SOCIAL MOVEMENTS (2000).

15. E.g., Charles Tilly, SOCIAl MOVEMENTS, 1768-2004 (2004).

16. E.g., LAW AND GLOBALIZATION FROM BELOW: TOWARDS A COSMOPOLITAN LEGALITY (Boaventura de Sousa Santos \& César A. Rodriguez-Garavito eds., 2005).

17. MUNCK, supra note 13, at 24.

18. See, e.g., STAMMERS, supra note 11, at 11-14.

19. E.g., Deborah Z. Cass, The Constitutionalization of the World Trade ORGANIZATION: LEGITIMACY, DEMOCRACY, AND COMMUNITY IN THE INTERNATIONAL TRADING SYSTEM (2005).

20. E.g., David Schneiderman, Investment Rules and the New Constitutionalism, 25 LAW \& SOC. INQUIRY 757 (2000). 
The principal argument advanced here is that the absence of social movements from the constitutional literature is not coincidental, but can be attributed to the potential difficulties they pose to some core elements of constitutional thought. In particular, bringing social movements into proximity with constitutional theory calls into question assumptions that constitutionalism is inherently institutional, Western in origin, and normatively positive. While such assumptions are emblematic of liberal constitutional theory, the extent to which they inform sociologically grounded accounts of the relation between globalization and constitutionalism is indicated by the difficulties encountered by the latter in accommodating a social movement perspective.

This article further claims that the tension between adhering to these assumptions and seeking to rework constitutional theory to remain relevant in the global age means that the issue of social movements can no longer be avoided. Moreover, doing so recovers the crucial insight that as well as its more familiar "top-down" conception, constitutionalism also has a "bottom-up" mode: constitutionalism from above necessarily coexists with constitutionalism from below. Accordingly, the assumptions detailed above sustain a partial account of the nature of constitutionalism. The conclusion of this article is that viewing constitutionalism from below as an integral part of constitutional discourse in fact strengthens the constitutional enterprise, enabling it to address two of its most trenchant critiques-namely that it is "a lousy description of power"21 and that its normative values are generally pressed into service of maintaining the position of elites. ${ }^{22}$

\section{SOCIETAL CONSTitutionalism, SOCIAL MOVEMENTS, AND THE SOCIOLOGY OF ABSENCE}

In one of the few attempts to consider the potential relevance of social movements from a legal perspective, Balakrishnan Rajagopal observes wryly that "[l]awyers generally do not concern themselves with mass politics or popular resistance." ${ }^{23} \mathrm{He}$ attributes this to the inability of mainstream legal discourse to accept or confront the epistemological limitations of a "unitary conception of the political sphere," which sees

21. David Kennedy, The Mystery of Global Governance, 34 OHIO N.U. L. REv. 827, 854 (2008).

22. Ran HiRschl, TOWARDS JURISTOCRACY: THE ORIginS AND CONSEQUENCES OF THE NEW CONSTITUTIONALISM 50-99 (2004).

23. Balakrishnan Rajagopal, InTERnational LaW From Below: DeVElopment, SOCIAL MOVEMENTS AND THIRD WORLD RESISTANCE 233 (2003). 
the state or the individual (and the relation between them) as the principal focus for scholarship. ${ }^{24}$ Rajagopal's analysis goes some way in explaining the historical absence of social movements within constitutional theory, especially its traditional, liberal conception where the state-civil society divide has long been an organizing principle. Much of the debate, though, over how constitutionalism should respond to globalization focuses on the ways in which the advent of multilevel governance undermines this "unitary conception" of politics, and seeks to reconnect constitutional ideas to the new, often deeply pluralistic, political relations of the global era. Might the time then be ripe to extend constitutional analysis to the activities of social movements?

This question is particularly acute for theories of societal constitutionalism, as the important innovations which this represents within constitutional discourse in terms of the latter's response to globalization might appear conducive to this enterprise. First, societal constitutionalism's sociological outlook sees the starting place for constitutional theory as the "is" of empirical observation rather than the "ought" traditionally favored by abstract normative approaches-and indeed can be read as warning against the dangers of conflating the two. As such, societal constitutionalism may be open to engagement with the constitutional implications of those analyses, which argue that if we are seeking to address the question of who are currently the key actors negotiating the nature and direction of global governance, social movements are necessarily part of the answer. Secondly, and related, societal constitutionalism is not hidebound by the statism implicit in a "public institutional prejudice" 25 which can be discerned in other accounts of "postnational constitutionalism." 26 Thus, in positing a broader conception of constitutionalism, which specifically includes economic sites such as corporations, societal constitutionalism would seem to invite reflection on whether this conception can also include other nonstate actors, such as social movements. Thirdly, rather than adopting the counsel of despair characteristic of some progressive scholars when conceptualizing globalization in constitutional terms, ${ }^{27}$ theorists of societal constitutionalism regard it as playing a role in addressing problems such as environmental destruction and the global

24. Id. at 236 .

25. Neil Walker, The Idea of Constitutional Pluralism, 65 MoD. L. REv. 317, 323 (2002).

26. Neil Walker, The EU and the WTO: Constitutionalism in a New Key, in THE EU AND THE WTO: LEGAL AND CONSTITUTIONAL Issues 31, 37 n.17 (Gráinne de Búrca \& Joanne Scott eds., 2001).

27. See James Tully, The Unfreedom of the Moderns in Comparison to Their Ideals of Constitutional Democracy, 65 MOD. L. REV. 204, 215 (2002). 
financial crisis. ${ }^{28}$ There is an interesting parallel here with claims made on behalf of social movements: they are engendering important changes to global power relations, amounting to a rival paradigm of globalization to neoliberalism in some versions. ${ }^{29}$

Nonetheless, as with constitutional discourse in general, there is little overt discussion of social movements in the societal constitutionalism literature. Where there is reference to the struggles in which they are engaged, there is the implication that "spontaneous indignation, unrest, [and] protest" are in some sense "remot[e] from philosophical, political, and legal discourses." 30 The argument presented here is that this absence is not an oversight or casual omission, but rather the absence highlights the embeddedness of certain patterns of thinking in the constitutional consciousness. Thus, while societal constitutionalism imagines a broader scope for constitutional discourse, the manner in which constitutionalism is seen to operate in these new settings reflects the continuing hold of key assumptions from the nation-state era, assumptions about the necessary institutional, benevolent, and Western nature of constitutionalism. However, a social movement perspective highlights the work done by these assumptions in narrowing the field of constitutional discourse and directs discussion to what is at stake for societal constitutionalism in defending this line against alternative constitutional readings that challenge these assumptions.

In what follows, we deploy the concept of the "sociology of absences" 31 to focus attention on societal constitutionalism's key method of generalization and respecification for translating constitutionalism to the transnational setting, and specifically to consider what the absence of social movements from this process reveals about the potential limitations of the former's understanding of constitutionalism. In doing so, we take seriously the sociological method of societal constitutionalism, and also the criticism that as it currently stands, the

28. See Gunther Teubner, Constitutionalizing Polycontexturality, in Gunther Teubner, Hans Lindahl, Emilios Christodoulidis, \& Chris Thornhill, Debate and Dialogue: Constitutionalizing Polycontexturality, 20 SOC. \& LEGAL STUD. 210, 210 (2011).

29. See Boaventura de Sousa Santos, Beyond Neoliberal Governance: The World Social Forum as Subaltern Cosmopolitan Politics and Legality, in LAW AND GLOBALIZATION FROM BELOW: TOWARDS A COSMOPOLITAN LEGALITY, supra note 16, at 29.

30. Gunther Teubner, Fragmented Foundations: Societal Constitutionalism Beyond the Nation State, in The Twilight of Constitutionalism? 327, 341 (Petra Dobner \& Martin Loughlin eds., 2010).

31. Rosana de Lima Soares, Absences and Emergences: Production of Knowledge and Social Transformation, 1 MATRIZES 231, 233 (2007) (Braz.). 
method is at times insufficiently sociological. ${ }^{2}$ Thus, if constitutionalism is broader than the traditional nation-state analysis, adverting to social movements inquires into what distinguishes its relocation to some nonstate sites, but not others. The question raised by the foregoing is whether societal constitutionalism falls into the same trap it warns against-of presenting the constitutional part for the whole.

\section{A. The Limits of Institutional Analysis}

When undertaking the task of "generalising" and "re-specifying" state-based approaches to constitutional theory in the context of globalization, Gunther Teubner urges that it is important to avoid the pitfall of "uncritically transferring nation-state circumstances to world society," 33 and so not to underestimate the scale of conceptual rethinking required. In this connection, one of the more specific dangers that societal constitutionalism appears to identify, with a view to avoiding, is to generalize constitutionalism while adhering to the "public institutional bias" referred to above. Thus, in contrast with other approaches to constitutionalism beyond the state, societal constitutionalism regards theorizing the constitutional attributes of supranational entities like the European Union (EU) or WTO as a necessary, but insufficient, response to globalization. Such approaches "confine the . . . relationship between juridification and constitutionalisation to the political community," 34 and so omit important phenomena from the scope of constitutional analysis, not only corporations, ${ }^{35}$ but also other autonomous subsectors including health, education, and the professions. ${ }^{36}$

However, while eschewing a public institutional bias, societal constitutionalism can be regarded as generalizing a broadly institutional conception of constitutionalism, and which, moreover, provides an important continuity not just with the nation-state tradition. This may, on its face, seem a counterintuitive claim: societal constitutionalism speaks in terms of the "fragmented foundations" of

32. See Chris THORNhILL, A SOCIOLOGY OF CONSTITUTIONS: Constitutions AND STATE LEGITIMACY IN HiSTORICAL-SOCIOLOGICAL PERSPECTIVE 5-6 (2011).

33. Gunther Teubner, Societal Constitutionalism: Alternatives to State-Centred Constitutional Theory?, in TransNational GOVERNANCE AND CONSTITUTIONALISM 3,5 (Christian Joerges, et al. eds., 2004).

34. Id. at 16.

35. See David Scitlli, Theory of Societal Constitutionalism: Foundation of a NON-MARXIST CRITICAL THEORY 40-41 (Teresa Sullivan ed., 1992).

36. See Teubner, supra note 33 , at 11 . 
constitutionalism beyond the state, ${ }^{37}$ and also warns against "[r]educing transnational governance to institutionalised politics." 38 The system's theoretical underpinnings of societal constitutionalism are generally seen as a challenge to statist thinking through its pluralistic conception of law, grounded in the social ubiquity of the binary coding of legal/nonlegal. ${ }^{39}$ However, while locating legal phenomena beyond the state, the law that is thereby being pluralized can also be seen to embody some of the key attributes of state law (which itself is theorized in systematic terms). In this regard, it has been observed that theories of reflexive law start "from a conception of the autonomy of law in the liberal state," 40 which is then extended to whichever social subsystem pluralist law is found. The argument outlined here is that in a similar fashion, theories of societal constitutionalism share with state-based accounts an institutionalized account of law and politics (and which, as we will see, is integral to maintaining the autonomy of constitutionalism in a nonstate context), and brings societal constitutionalism closer to state constitutionalism in terms of its modus operandi than is sometimes appreciated.

The language of institutionalization features heavily in the societal constitutionalism literature. In David Sciulli's influential analysis, the only effective counter to the 'massive evolutionary drift' of modern society is to be found in "institutions of external procedural restraint." 41 As developed by Gunther Teubner, the prerequisite to societal constitutionalism is "social institutionalization."42 Tellingly, his qualification of traditional understandings of the "polity" in constitutional theory as "institutionalized politics" is to stress that the former also includes "nonpolitical institutions of civil society." 43 The point being made here is not simply semantic: rather, it highlights the similar ways that institutionalization is understood in both societal and state-focused accounts of constitutionalism. First, as with traditional accounts, for societal constitutionalism, institutional settings are necessarily where processes of constitutionalization unfold. A core tenet of societal constitutionalism is that juridification entails constitutionalization, leading directly to its central thesis of a

37. Teubner, supra note 30 , at 327 .

38. Teubner, supra note 28 , at 214.

39. See Brian Z. TAMANaha, A General JuRisprudence of LAW AND SocietY 186 (2001).

40. Boaventura de sousa Santos, Toward a New Legal Common Sense: Law, GLOBALIZATION, AND EMANCIPATION 57 (2d ed. 2002).

41. ScIULLI, supra note 35 , at 81 .

42. Teubner, supra note 33 , at 18.

43. Teubner, supra note 30 , at 333 (emphasis added). 
multiplicity of civic constitutions. ${ }^{44}$ However, to complete the circle suggested by Teubner's formulation above, it seems clear that for societal constitutionalism, institutionalization is also the prerequisite for juridification. Thus, societal constitutionalism can be regarded as distancing itself from a particular sense of constitutionalism's institutionalization in the nation-state, not its institutional character in general. Moreover, the institutions of civil society which are discussed bear a strong family resemblance to the state institutions of traditional constitutional scholarship: Sciulli's "collegial formations" are typically characterized by a significant degree of formal organization and hierarchical structure, and include bodies such as professional associations, corporations, universities, and hospitals.45 And while Teubner speaks of the "dual constitution of organized and spontaneous sectors," his describing the latter primarily in terms of a "market-constituted spontaneous sector," 46 suggests that this does not encompass the forms of popular resistance represented by social movements.

The imperative behind this exclusion of the noninstitutional becomes clearer when we consider why it is important for the societal constitutionalism project to retain, in adapted form, the institutional template of the nation-state era. We should recall that for Teubner, the "historical role" of constitutions has been to secure social differentiation in the face of the swamping tendencies inherent in modern society. Crucially though, this function is discharged by both state and civil constitutions. What is implicit is that both forms, but only those forms, have the capability to bring about such outcomes, achieved in practice by subsequent processes of juridification and constitutionalization: forms which lack the sufficient institutional indicia are necessarily incapable of performing this task. This leads him to conceptualize constitutionalism primarily in terms of the "legally institutionalized guarantees of a self-restraint of politics." 47 Thus, what is being generalized from the state setting are constitutionalism's mutually reinforcing qualities of institutional capacity and legal autonomy, which are now ascribed to the civic constitutions of civil society to ensure the legal constraint of arbitrary power at the transnational level.

It is important to emphasize that what we are discussing here goes beyond semantics. To reinforce this point, we consider how the preceding discussion relates to differing theoretical orientations of globalization. When theorists speak of globalization simpliciter, they

44. See Teubner, supra note 33 , at 8 .

45. See ScIULII, supra note 35 , at 80 .

46. Teubner, supra note 33, at 27-28.

47. Id. at 12 . 
often only have globalization from above in mind. Studies of this form of globalization focus upon the "ideological and operational aspects of globalization" whereby "transnational market forces dominate the policy scene, including the significant co-optation of state power," 48 and consequently emphasize the shift from regulation to governance. Taking as their point of departure the divergence of scale between national law and global economic activity, they seek to expand analyses of law and globalization by theorizing nonstate regulatory forms. ${ }^{49}$ However, Santos argues that while this takes us beyond a narrow formal conception of law, it is a highly partial account, which focuses almost exclusively upon "the most visible, hegemonic actors," such as multinational corporations. ${ }^{50}$ These actors are regarded as playing a central role in overcoming regulatory issues which states and markets alone cannot resolve through "collaborative networks involving firms and secondary associations." 51 This presents a somewhat technocratic vision of "horizontal collaboration . . . by pragmatist governance" 52 driven by elites, and which stresses the importance of "social engineering and institutional design." 53 On this account, social movements, and the constituencies represented by them, are irrelevant. The social movements are only incorporated, if at all, once the "institutional blueprint" has been fully established. ${ }^{54}$

However, for Santos, the emergence of transnational networks of social movements in resistance to neoliberalism as a distinctive form of globalization from below underscores the partiality of regarding this top-down account as exhausting our knowledge of globalization. ${ }^{55}$ Accordingly, if globalization is reconfiguring our understandings of constitutionalism, this perspective asks why it should be presumed that only the most hegemonic forms of globalization are pertinent to working out that process. For analysts of global social movements, if we divert our attention from social science's traditional preoccupation with the top-down workings of institutions, we can recover some overlooked insights into the nature of social interaction and transformation.

At the heart of the contemporary social movement literature is the claim that institutional settings do not exhaust the options for political

48. FALK, supra note 7 , at 130.

49. See Boaventura de Sousa Santos \& César A. Rodriguez-Garavito, Law, Politics, and the Subaltern in Counter-Hegemonic Globalization, in LAW AND GLOBALIZATION FROM BELOW, supra note 16 , at 1, 5-6.

50. Id. at 2 .

51. Id. at 7 .

52. Id.

53. Id. at 5 .

54. See id. at 9.

55. See Santos, supra note 29 , at 43. 
engagement. Empirical analyses of social movements chart the disillusionment with institutional politics as a means of promoting emancipatory change, and the turn towards less formal mechanisms such as mass protest and nonviolent civil disobedience. ${ }^{56}$ It should be stressed, as will be discussed later, that the institutional dimension does not disappear within this framework, as often the ultimate aim of social movement mobilization is some transformation within institutions themselves. Rather, the main thrust of social movement analysis is that we need to reassess our understandings of institutions in terms of their necessary-and always existing-relation with the noninstitutional. Indeed, in the global context, this relation is seen as embodying the dynamic for many pressing issues of the age, such as environmental degradation ${ }^{57}$ or international labor standards. ${ }^{58}$ In the present context, it is important to stress that the global context takes us beyond the contrast social movements and state institutions, as the former can also be differentiated from the institutional constituents of societal constitutionalism.

For Robert O'Brien and his co-authors, one of the key political developments of recent times has been the direct engagement between social movements operating in transnational mode and the major players in the global economy. ${ }^{59}$ This engagement forges a relation between actors not traditionally encompassed within state representative politics: powerful economic institutions, such as the World Bank, the WTO, and transnational corporations on the one hand, and on the other, social movements and the often disenfranchised groups on whose behalf they act, such as indigenous peoples and the poor.

If constitutionalism is concerned with the legal restraint of politics, the omission of social movements from constitutional discourse would appear to unduly narrow the scope of political action that the latter can encompass. In contrast, as a consequence of the mobilization of social movements on a transnational scale, what is counted as within the sphere of the political is itself now open to question. ${ }^{60}$ There is a more

56. See generally Geoffrey Pleyers, ALter-Globalization: BECOMING ACTORS IN THE GLOBAL AGE (2010) (undertaking empirical analyses of transnational social movements to identify methods beyond formal institutions of affecting social and political change).

57. See MUNCK, supra note 13, at 102-06.

58. See César A. Rodriguez-Garavito, Nike's Law: The Anti-Sweatshop Movement, Transnational Corporations, and the Struggle Over International Labor Rights in the Americas, in LAW AND GLOBALIZATION FROM BELOW: TOWARDS A COSMOPOLITAN LEGALITY, supra note 16 , at $64,64-66$.

59. O'BRIEN ET AL., supra note 14, at 2.

60. MUNCK, supra note 13 , at 28. 
fundamental point here. Namely, within this broader conception of politics, assumptions about the institutional capacity of either state or societal constitutionalism become more difficult to sustain. On the one hand, social movements, by employing extra-institutional means, seem to be able to frustrate the ability of institutional actors to exercise constitutional constraint; 61 on the other, social movements themselves often emerge as more efficacious vehicles for constraining and reshaping oppressive political relations. ${ }^{2} 2$ The social movement literature thus posits an alternative understanding of social development and change, where the institutional can only properly be understood through its relation to the noninstitutional. As such, it raises the disturbing prospect for societal constitutionalism that in discharging the task of generalizing and respecifying, it seeks to reinscribe, at the level of transnational constitutionalism, ideals of autonomy and capacity that never pertained in the context of the nation-state. ${ }^{63}$

\section{B. Social Movements and Constitutional Asymmetries of Power}

A social movement perspective also brings to light, and directs critical attention to, assumptions underpinning why societal constitutionalism believes it is important to fashion constitutional solutions to problems of global governance. It is possible to read societal constitutionalism solely at a sociological level, mapping out the new-and fuller-terrain of global governance that is revealed once we abandon the constraints of state-centered thinking. However, it also has a deeply normative dimension. In essence, this rests on the view that constitutionalism in the nation-state context should be seen in broadly positive and benevolent terms, operating as a force for social good. It should be recalled that, for Teubner, the central function of constitutionalism is distilled to guaranteeing social differentiation against the authoritarian pressures of evolutionary drift. Thus, the value of undertaking the contemporary generalization and respecification of constitutionalism is to ensure that these benefits are

61. See César A. Rodríguez-Garavito \& Luis Carlos Arenas, Indigenous Rights, Transnational Activism, and Legal Mobilization: The Struggle of the U'wa People in Colombia, in LAW AND GLOBALIZATION FROM BELOW: TOWARDS A COSMOPOLITAN LEGALITY, supra note 16, at 241, 241-44.

62. See Munck, supra note 13 , at $75-93$ (discussing case studies where social movements have played a role in global governance).

63. This argument follows Santos's critique of systems theoretical theories of law in general, that by basing their approach in "conception of the autonomy of law in the liberal state," which is then extended to reflexive law of social sub-systems, they are "devolving to modern state law what it never had." SANTOS, supra note 40, at 57-58. 
available in the global age. In other words, more constitutionalism is regarded as part of the solution to problems of global governance.

For Teubner, societal constitutionalism is at its optimal when the structural coupling between autonomous legal and social processes restrains both the various constitutions generated by social institutions, and the constitutions of institutionalized politics, in terms of their "possibilities of influence." 64 However, the problem of structural corruption in the context of global governance-exemplified, for example, by the financial crisis which began in 2008-means that where the emphasis was previously on liberating social sectors from state politics, now the central issue is how to place effective limits on self-regulating nonstate constitutional forms. Teubner argues that societal constitutionalism is well placed to respond to this "dynamic disequilibrium," by "steer[ing] a difficult path between external interventions and pressures towards self-limitation."65 This is to be achieved through a form of "hybrid regulation" whereby an admixture of "[p]olitical-legal regulation and external social influence" applies pressure to the subsystem in question: however, the precise prescription for particular problems cannot be known in advance. 66

However, adverting to the actual political contexts from which social movements have emerged presents a quite different historical perspective on constitutionalism. Highly relevant here is the setting of post-colonial societies, where, from the viewpoint of the colonized, constitutional strategies have more often sought to erode rather than strengthen social differentiation. ${ }^{67}$ We can make two important points in this connection. First, that it is impossible to fully understand the nature of modern constitutionalism-state or societal-without taking into account the imperial context. ${ }^{68}$ Accordingly, when societal constitutionalism is generalizing from the Western state tradition, it should also be seen as generalizing from that state tradition as informed by the imperial encounter. Secondly, the effects of imperialism and colonialism on constitutional discourse continue to reverberate today. For example, the emphasis upon binary coding as foundational to societal constitutionalism can be seen to take account of the ways in which the power to name social phenomena as legal or illegal is removed

64. Teubner, supra note 33 at, 20.

65. Teubner, supra note 28 , at $223,225$.

66. Id. at 225 .

67. See generally James TUlly, STRANGe MultiPlicity: Constitutionalism IN AN AGE OF DIVERSITY 58-98 (1995) (exploring the historical tendency to cultural uniformity in modern constitutionalism).

68. See Scott Veitch, Authority, Exploitation and the Idea of Public Law, in Public LaW ANd Politics: The Scope and Limits of Constitutionalism 27, 31 (Emilios Christodoulidis \& Stephen Tierney eds., 2008). 
from certain groups. This is particularly acute in reference to social movements, as their activities are often directed to what would be seen as the nonlegal, or even alegal, in terms of the conventional understandings of law. 69

Reference to the colonial and postcolonial contexts amplifies a more general concern that has been raised over societal constitutionalism's relationship to questions of power. In that connection, Chris Thornhill has elsewhere argued that at the level of "power theory," Teubner's account of constitutionalism is grounded in "an original homology between statehood and society's politicality." 70 However, taking as the antecedent the classical state theory which societal constitutionalism more generally seeks to transcend leads, he contends, to a neglect of "transformations that occur within political power as an autonomous medium of social exchange." 71 Bringing social movements into view helps explain why it is important for societal constitutionalism to avoid engaging with a broader conception of power constellations. Crucially, the top-down institutionally focused model presumes a certain leveling of power such that social actors can deliberate with each other on relatively equal terms. However, globalization from below directs discussion to the-as yet unrealized-preconditions, which would enable this collaborative governance to occur, in particular the "redistribution of resources to counter power asymmetries." 72 Accordingly, in drawing attention to this tendency "to bracket deep power asymmetries among actors,"73 social movements direct the debate precisely to questions of the relation between power and constitutionalism, which theories of societal constitutionalism seek to avoid.

\section{Interrogating the Western Origins of Constitutionalism}

A social movement perspective also illuminates a third assumption informing societal constitutionalism, namely that the theory and practice of modern Western constitutionalism provide the default setting for discussing constitutionalism in a global context. Such assumptions are particularly prevalent in the public institutional approaches to constitutionalism beyond the state, where lists of innate characteristics of constitutionalism tend to include structural features of

69. See SANTOS, supra note 40, at 61-66.

70. Chris Thornhill, Constitutional Law from the Perspective of Power: A Response to Gunther Teubner, in Debate and Dialogue: Constitutionalizing Polycontexturality, supra note 28 , at 244,246 .

71. Id. at 245 .

72. Santos \& Rodríguez-Garavito, supra note 49 , at 8.

73. Id. 
Western constitutions, including judicial review, separation of powers, and means for resolving hierarchical claims between official norms. ${ }^{74}$ Within such accounts, the relative position of (some more, some less) constitutionalized supranational entities leads to constitutionalism being posited as a continuum, in contrast to measuring its presence in all-or-nothing terms. However, what is sometimes overlooked in this formulation is that it is constitutionalism as developed within the Western nation-state, which is presumptively at the widest end of that continuum. This formula embodies all the requisite constitutional qualities which, in suitably adapted form, are now to be located in nonstate fora. Theories of societal constitutionalism, though, appear to offer a different mode of analysis in which constitutionalism does not develop chronologically from the state to the nonstate environment. Moreover, its insistence that constitutionalism subsists as a set of "procedural-normative restraints on arbitrary exercises of collective power" 75 moves it away from attempts to catalogue whether a sufficient mass of constitutional mechanisms can be found in any putative constitutional site. However, notwithstanding these ostensible divergences, it is argued that societal constitutionalism's approach to the relation between globalization and constitutionalism can be regarded as an extension of existing debates within Western constitutional thought.

In one of his last published essays, David Sciulli set out a clear and spirited defense of societal constitutionalism's distinctiveness. Sciulli argued that once properly understood, this distinctiveness counters any charges of particularism which may be leveled against it. In contrast with Anglo-North American approaches, which locate the constraining power of constitutionalism in the "constituent force' in civil society," and the continental European tradition, where "the aura and majesty of the state" performs this function, he argues that it is only societal constituents that can fully account for the bright line restraints of limited government. ${ }^{76}$ These constituents, found in both civil society and the agencies of state, are "the participants in any structured situation who, in simply advancing their own immediate positional and corporate interests, simultaneously establish and then maintain the integrity of a

74. See, e.g., Walker, supra note 26 , at 35,56 .

75. David Sciulli, Societal Constitutionalism: Procedural Legality and Legitimation in Global and Civil Society, in LEGALITY AND LEGITIMACY: NORMATIVE AND SOCIOLOGICAL APPROACHES 103, 104 (Chris Thornhill \& Samantha Ashenden eds., 2010) (emphasis removed).

76. Id. at 103-04. 
collegial (or deliberative) form of organization and of the threshold standard of procedural integrity."77

In emphasizing this procedural threshold standard for guarding against caprice, two important points follow for Sciulli. First, that there cannot be "any set of ultimate substantive-normative restraints on arbitrariness"78 that can generate sufficient consensus to operate across cultures ( $a$ fortiori in the transnational context.) ${ }^{79}$ Second, by occupying these positions, societal constituents enable every other actor "to identify bright line thresholds of 'progress' or 'regress"' when it comes to evaluating specific policy proposals. ${ }^{80}$

Sciulli finds this analysis especially pertinent with regard to those who see social movements as a vehicle of social emancipation, arguing that any attempt to construct a constitutional order that seeks to benefit the poor and the weak necessarily does so at the expense of procedural integrity. ${ }^{81}$ For Sciulli, the danger is that without the structural underpinnings of procedural restraint provided by societal constituents, the substantive rationality embodied by social movements can (and on his reading of the historical record, does) easily lapse into autocracy. ${ }^{82}$ One can acknowledge that Sciulli raises important questions about the potential hegemonic nature of substantive rationality - and note in passing that such questions are by no means absent from the social movement literature ${ }^{83}$-while querying the implication that they uniquely arise for theorists of social movements.

Sciulli's analysis appears to confirm societal constitutionalism's close affinity with globalization from above. Professional groups, expressly including corporations-and which in many renderings are seen as integral in constructing globalization from above 84 -are valorized as their disinterested deliberations pursue responsible and impersonal interests consistent with lawfulness (as opposed to the "commitment to correctness or right" of social movements). ${ }^{85}$ There is a crucial contrast here with analyses of globalization from below which emphasizes that social movements embody a different type of

\footnotetext{
77. Id. at 119.

78. Id. at 104.

79. Id.

80. Id. at 119 .

81. Id. at 118 .

82. Id. at 119.

83. See, e.g., MUNCK, supra note 13, at 110-26.

84. See, e.g., Yves DEZALAY \& BRYANT G. GARTH, DEALING IN VIRTUE: INTERNATIONAL COMmERCial ARBITRATION AND the CONSTRUCTION OF A TRANSNATIONAL LEGal ORDER

85. Sciulli, supra note 75 , at 120 .
} (1996). 
lawfulness, on Santos's terms, a "subaltern cosmopolitan legality." 86 Each represents not just a different paradigm of globalization, but of law. Sciulli's version of societal constitutionalism cannot, on procedural-normative grounds alone, tell us which amounts to lawfulness, and which does not. Given the cross-cultural differences, which underpin the opposing paradigms, on Sciulli's own terms we cannot expect to generate a consensus on this issue-particularly once we locate them in global context. This places societal constitutionalism in a bind: on the one hand, globalization from below is said to represent the type of substantive-rationality which is impermissible under the procedural model, but on the other, to exclude it requires societal constitutionalism to flout its own injunction against privileging one substantive-rationality over another. ${ }^{87}$

As such, Sciulli's arguments become open to the critique advanced vis-à-vis the global spread of liberal rights beyond North America and Western Europe. Namely, that the emphasis on the procedural guarantees masks a substantive project, and moreover one whose effect, if not motive, is to entrench the present-from the perspective of globalization from below, inequitable-global distribution of resources. 88 If globalization from below highlights the paradigmatic nature of current debates, societal constitutionalism seeks to foreclose that debate by denying paradigmatic status to the former. But to do so requires societal constitutionalism to reveal its own paradigmatic colors. In seeing globalization from above exclusively as a site of legal and constitutional production, societal constitutionalism draws on institutional understandings of legality as developed within Western modernity. Presenting this as the only option available denies the politics of definition which are always in play when assigning the label law to some social phenomena and not others. ${ }^{89}$

This connects to the more general point that the overall effect of the three assumptions discussed above is a depoliticization of constitutional discourse. Adapting David Harvey, they reinforce the preferred model of neoliberal rule through technocratic governance by elites, with the

86. SANTOS, supra note 40 , at 465 .

87. Moreover, such substantive-normative rationality would appear required to elaborate what in practice constitutes the "responsible" and "impersonal" behavior of professional actors, and similarly how social movements should confine themselves, as Sciulli appears to suggest, to "obviously just goals." Sciulli, supra note 75, at 120 (emphasis removed).

88. See David Schneiderman, Comparative Constitutional Law in an Age of Economic Globalization, in DEFINING THE FIELD OF COMPARATIVE CONSTITUTIONAL LAW 237, 238 (Vicki C. Jackson \& Mark Tushnet eds., 2002).

89. See GAVIN W. ANDERSon, CONSTitutional Rights AFter Globalization 107-15 (2005). 
corollary that questions of resource allocation are best left to experts in the field..$^{90}$ Indeed, for Sciulli, the fear that everything might become politicized underpins the procedural turn of societal constitutionalism. ${ }^{91}$ However, in challenging these assumptions, and in particular by locating this challenge in the paradigmatic debate between globalizations from above and below, social movements suggest that processes of politicization cannot be avoided. Thus, any account of the relation between globalization and constitutionalism that seeks to obscure these movements, is itself necessarily partial. Accordingly, a social movement perspective suggests that if our objective is to map the relation between globalization and constitutionalism, it requires a fuller approach that moves beyond the assumptions informing theories of societal constitutionalism.

\section{SOCIAL MOVEMENTS IN CONSTITUTIONAL THEORY}

The arguments outlined in the previous section support the claim that social movements' habitual exclusion from constitutional discourse is not an oversight, or simply coincidental, but can be attributed to the critical spotlight they shed upon assumptions about constitutionalism's necessary institutional, benevolent, and Western-originated character, which constitutional theory would generally prefer to leave undisturbed. In the remainder of this paper, we turn from explaining the absence of social movements to theorizing the implications of their presence. The argument advanced here is that undertaking such an exercise is not to be feared, and moreover is essential both in terms of the sociological ambition of societal constitutionalism of enhancing our understanding of constitutionalism itself, but also with regard to its normative aim of ensuring that power is held to account. In other words, constitutionalism not only can, but indeed must, transcend the limitations of the assumptions delineated above.

Before proceeding, it is important to address a potential definitional objection to the inclusion of social movements within constitutional theory. This would argue that it is one thing to say that focusing upon social movements causes us to reevaluate the extent to which constitutionalism embodies certain qualities, but quite another to regard the former as constitutional sites in their own right. Put differently, it is a considerable leap from critical perspective to constitutional subject. However, following societal constitutionalism's sociological method to its logical conclusion shows that social

90. See David HaRvey, A BRIEF History OF NEOLIBERALiSM 65-66 (2005).

91. Sciulli, supra note 75 , at 121. 
movements are always already a component part of constitutional discourse. This claim builds on the key insight of societal constitutionalism that the normative enterprise of mediating between diverse and often antagonistic interests provides a crucial framing mechanism for the exercise of power that can be broadly located within human society. But if ubi societas, ibi costituo, we should also take seriously the criticism that societal constitutionalism is insufficiently sociological when it tethers itself too rigidly to the particular form of society that developed within the contours of Western liberalism. ${ }^{92}$ In doing so, societal constitutionalism places ways of framing the exercise of power which draw on alternative imaginings of society beyond the constitutional pale. And if, as argued above, theories of constitutionalism are, in Sciulli's terms, necessarily substantive normative rationalities, when the range of such possible rationalities is reduced to one, what is excluded remains no less constitutional. Thus, considering the constitutional relevance of social movements serves to remind that any putative positing of constitutionalism is always open to the question of what is excluded. The argument advanced below is that social movements, as key protagonists within globalization from below, provide such an alternative account of constitutionalism.

\section{A. From Globalization from Below to Constitutionalism from Below}

In setting out the argument that an-until now-obscured constitutionalism from below has always been present alongside the more visible constitutionalism from above, there are some helpful analogies to be drawn with the emergence of globalization from below as a distinctive paradigm. As discussed above, during the height of the "Washington consensus," globalization tended to be depicted in singular terms, and largely equated with the hegemonic sway of neoliberalism. However, over the past decade, and coinciding with the greater prominence of social movement activism, it has been argued that there are now two rival paradigms of globalization. ${ }^{93}$ Variously described as counter-hegemonic globalization, or, more commonly, globalization from below, the second paradigm challenges the idea that neoliberal "horizon[s] of feasibility" 94 provide the only, or indeed inevitable, path of

92. See Thornhill, supra note 70 , at 245 . Thornhill argues that in tying itself too rigidly to an "over-literal" view of statehood, societal constitutionalism thereby discounts "the wider history of the formation of political power in modern societies." $I d$.

93. Santos, supra note 29 , at 29.

94. Richard Falk, Global Climate Change, Human Security and the Future of Democracy, in Global CRISES AND THE CRISIS OF GLOBAL LEADERSHIP 89, 105 (Stephen Gill ed., 2012). 
global development. In its place, it offers a noncapitalist, nonviolent vision of global transformation, which moves "beyond liberalism and real socialism." 95

The terms of engagement between these two paradigms are extensively discussed elsewhere, but for present purposes, there are two points to highlight from this debate. First, theorists of globalization from below are engaged in the task of recovery not discovery, and are drawing attention to the opposition to neoliberalism, which was always there alongside it, but often lost in late twentieth century narratives about the end of history. In other words, the seeds of globalization from below were planted long before protests in Seattle and Genoa caught the world's attention. Following from this, one of the consequences of politics and law being increasingly conceived of in global terms is that "below" is shedding the obscurity that prevailed within state-focused approaches. In part, this can be attributed to changes in the media. For example, worldwide access to YouTube, leading to greater visibility of protest and unrest, ${ }^{96}$ is an indication that neoliberalism has been signally unable to contain its own contradictions. ${ }^{97}$ Bringing these points together, it has been suggested, updating Polanyian terminology, that globalization from below is part of a contemporary double movement, representing society's latent capacity for self-protection against the resurgent project of embedding society in the economy. ${ }^{98}$

We argue here that these antagonisms between globalizations from above and below are replicated in the constitutional context, highlighting important ways that current theories of societal constitutionalism can be developed. It is now commonplace that globalization from above has given rise to new constitutional relations, of both a formal and informal nature. Critics of this constitutionalization of economic globalization argue that it represents a framework for the exercise of power, which places the pursuit of policy options antithetical to neoliberalism beyond the reach of democratic majorities..$^{99}$ There is possibly more critical purchase in interrogating the reduction of debates about the relation between globalization and constitutionalism to the latter's nexus with globalization from above. While presumably not their intention, one effect of this exclusivity is to remove from these debates the vision offered by a globalization from below as a potential alternative way of framing global power

95. ENRique Dussel, Twentr Theses on POLITICS at xvi (2008) (emphasis removed).

96. See MASON, supra note 1, at 33-37.

97. See SANTOS, supra note 40 , at 10.

98. See MUNCK, supra note 13, at 34-39.

99. See David SCHNEIDERMan, Constitutionalizing EConomic Globalization: INVESTMENT RULES AND DEMOCRACY'S PROMISE 9-10 (2008). 
relationships. This is particularly pertinent with regard to societal constitutionalism, as its methodological aversion to accommodating globalization from below can be seen as an attempt to exclude the antagonisms, which the latter brings to light from constitutional discourse. But as, when called upon to justify this approach, societal constitutionalism is ultimately required to state its substantive preference for globalization from above as the framework for resolving questions of global governance, in practice it cannot eliminate these antagonisms. In other words, societal constitutionalism does not overcome the "irreducibly antinomic" 100 nature of constitutional discourse, but rather displaces it to the transnational sphere where the tensions between opposing paradigms of globalization make it more difficult to avoid than in national settings.

Acknowledging this irreducible antinomy, it is suggested, is the necessary starting point for theorizing the connections between globalization and constitutionalism. This does not mean that we should not, or cannot, address the question of how to take seriously the empirical fact of social and cultural pluralism, but that doing so cannot be achieved by the suppression of genuine and reasonable differences entailed by the reduction of constitutionalism to constitutionalism from above. In that connection, we can highlight a growing literature which, though not always couched in self-consciously constitutional terms, can be seen to represent a nascent school of constitutionalism from below. The starting point here is to reconnect constitutional discourse with popular forms of politics which are of most relevance to the bulk of the planet.101 For Enrique Dussel, connecting to these developments, as embodied through various "political springs," requires a new theoretical approach based in a "coherent interpretation of the profound transformation that . . people are experiencing." 102 It is argued that doing so recasts received histories, for example, to highlight the inherently bottom-up and social dimension to struggles about rights in contrast with their more top-down and individualistic conception in the Western canon. 103

In constitutional theory, recent scholarship has sought to recover an alternative history-and future - of constitutionalism beyond the institutional realm. On this account, constitutionalism has always

100. Emilios Christodoulidis, Against Substitution: The Constitutional Thinking of Dissensus, in THE PARADOX OF CONSTITUTIONALISM: Constituent POWER AND CONSTITUTIONAL ForM 189, 191 (Martin Loughlin \& Neil Walker eds., 2007).

101. Partha Chatterjee, The Politics of the Governed: Reflections on Popular POLITICS IN MOST OF THE WORLD 3 (2004).

102. DuSSEL, supra note 95 , at $\mathrm{xv}$.

103. See STAMmERS, supra note 11, at 40-69. 
consisted of the relation between the formal (institutional) and the informal (noninstitutional). Returning to the colonial context underlines this point: for Tully, notwithstanding the imperial preference for institutional uniformity, the hidden constitutions of indigenous societies were never fully extinguished, and indeed continued to inform indigenous settler relations. ${ }^{104}$ The resurgence of indigenous constitutional ideas as part of globalization from below confirms that they should not be seen as "simply minor disturbances on the frontier of modern constitutionalism," 105 but as equally important constitutional products of the imperial relationship as the more visible forms of constitutionalism from above. Tully characterizes the present geopolitical conjuncture in terms of an informal imperialism: by comparison with the gunboat, the objective here is to normalize the prerogative of the West to trade on its own terms with non-Western societies, and, if necessary, to supplant local constitutional forms which provide obstacles to its realization. ${ }^{106}$ However, his analysis here is that again this supplanting has not been wholly successful, as evidenced by the myriad forms of extra-institutional resistance to neoliberalism. ${ }^{107}$ In this regard, he argues that we should conceive of globalization in terms of the relation between state and supranational constitutional forms on the one hand, and on the other, those constituent powers found both within and outside the structures of representative democracy. The latter is comprised of decolonization and internationalist movements, as well as alternative NGOs and bodies which escape traditional categorization, such as the World Social Forum. ${ }^{108}$

\section{B. Constitutionalism from Below and Social Transformation}

Constitutionalism from below not only stands for a different approach to framing the exercise of political power, but also rests on a different understanding of the nature of that power. Within traditional constitutional theory, radical change takes place through the exercise of constituent power, which, once galvanized, reforms the institutions of

104. See TULLY, supra note 67 , at 99-101.

105. Id. at 99 .

106. James Tully, On Law, Democracy and Imperialism, in PUBLIC LAW AND PoLITICS: THE SCOPE AND LIMITS OF CONSTITUTIONALISM, supra note 68, at 69, 97.

107. James Tully, The Imperialism of Modern Constitutional Democracy, in THE PARADOX OF CONSTITUTIONALISM: CONSTITUENT POWER AND CONSTITUTIONAL FORM, supra note 100 , at 315,337 .

108. Id. at 321. See also Ruth Buchanan, Legitimating Global Trade Governance: Constitutional and Legal Pluralist Approaches, 57 N. IR. LEGAL Q. 1, 9 (2006). 
state and the baselines for permissible constitutional conduct. ${ }^{109}$ Within theories of societal constitutionalism, constituent power is necessarily more diffuse and not confined to formal politics; however, each social subsystem is open to its own constitutional moment where a decision has to be made "between the total destruction of [its growth-energies] and its self-limitation."110 In each case, the ultimate question for constitutional theory is when the prevailing institutional order should be dismantled, and how it can be remade. The imperative of reconfiguring constituent power so that prevailing institutional arrangements can be transformed also informs critical constitutional theory. 111 However, it has been argued that this succumbs to the "the hegemony of hegemony,"112 that is, seeing institutions as something to be captured and exercised differently risks replacing one particularistic articulation of power interests with another.

The modus operandi of social movements, however, is not geared towards reordering the established institutional framework of power. Rather, their extra-institutional forms of direct action are better captured under the heading of the nonhegemonic, denoting how they seek to "refuse, rather than rearticulate"113 the forces of neoliberalism: accordingly, they seek to transcend, not capture, the container of institutional power, whether that of state or societal constituents. As such, globalization from below is said to move beyond the reform or revolution cleavage which has informed modern political struggle. The objective of entities such as the World Social Forum is not to seize power, "but rather to change the power relations in oppression's many faces,"114 and which accordingly prioritizes pragmatic, often incremental, strategies of change.

In this connection, Santos highlights a number of important ways in which social movement activism expands the politics of legality. First, this sees legal mobilization always within broader processes of political mobilization; thus, the subaltern cosmopolitan legality, which is thereby propagated is a political strategy comprising legal elements. Secondly, (and addressing concerns regarding the potentially totalizing nature of such legality), the focus of these struggles is not, as was historically the

109. See, e.g., 1 Bruce Ackerman, We The People: Foundations (1993) (discussing the U.S. Constitution).

110. Gunther Teubner, A Constitutional Moment? The Logics of "Hitting the Bottom", in The Financial Crisis in Constitutional Perspective: The Dark Side of Functional DifFERENTIATION 3, 12 (Poul F. Kjaer et al. eds., 2011).

111. See Michael HaRdT \& ANTONIO Negri, EMPIRE 356-59 (2000).

112. Richard J.F. Day, From Hegemony to Affinity: The Political Logic of the Newest Social Movements, 18 CULTURAL STUD. 716, 725 (2004).

113. Id. at 730 .

114. Santos, supra note 29 , at 51. 
case for emancipatory politics, solely directed towards social redistribution, but instead rests "on a complex and dynamic balance between the principle of equality and the principle of recognition of difference." 115 Thirdly, where law is employed, it is as likely to be "local unofficial law" as state or transnational law, thus underscoring the "transcalar nature of legal mobilization."116 Finally, and following the legal struggles entered into by social movements, it draws on a diverse range of legal knowledge, going beyond its (state or societal) professional strain to include that produced, inter alia, by indigenous peoples, landless peasants, migrants, peace activists, and those working in the informal economy. ${ }^{117}$

From the perspective of systemic understandings of law, social movements thus present a "rather messy and potentially uncategorizable" picture. ${ }^{118}$ However, to the extent that this is seen to be a fuller and more representative account of contemporary legal and political struggle, it also propels us to think beyond the ordered surfaces and planes generally associated with constitutionalism. One promising alternative is provided by theories of nodal governance, which begin from the premise that a proper understanding of how power is exercised and dispersed is a necessary precursor to procuring just and competent forms of governance. ${ }^{119}$ To that end, society is conceived in terms of the interaction between various collectivities, which leads to (not always intentional) outcomes that include social goods, such as economic growth or general well-being, and social problems, such as poverty or illness. Nodes are connected to each other through networks: a node can be one point within a single network; it can be connected with other nodes in a plurality of networks; or it can be a "superstructural node," in which various collectivities put together their resources in pursuit of a shared objective. ${ }^{20}$

The framework of nodal analysis thus provides a means of accommodating the horizontal legal and political relations described in the social movement literature. Under this approach, distinctions, such

115. Id. at 61 . Santos elsewhere elaborates on the nature of that relationship: "people have the right to be equal whenever difference makes them inferior, but they also have the right to be different whenever equality jeopardizes their identity." Boaventura de Sousa Santos, Human Rights as an Emancipatory Script? Cultural and Political Conditions, in ANOTHER KNOWLEDGE IS POSSIBLE: BEYOND NORTHERN EPISTEMOLOGIES 2, 28 (Boaventura de Sousa Santos ed., 2008).

116. Santos, supra note 29 , at 61 .

117. Id.

118. Ruth Buchanan, The Constitutive Paradox of Modern Law: A Comment on Tully, 46 OSGOODE HALL L.J. 495, 497 (2008).

119. Scott Burris et al., Nodal Governance, 30 AustL. J. LEGAL PHIL. 30, 31 (2005).

120. Id. at 38 . 
as those between official and nonofficial, are unimportant, and moreover, obfuscatory. While state and societal institutions are important nodal points, they have no privileged analytical position. ${ }^{121}$ To take the example of recent transnational struggles over the protection of intellectual property rights, a nodal analysis accords appropriate weight to the actions of societal constituents, in particular the U.S. pharmaceutical corporations. Burris and his collaborators argue that through activating a superstructural node, these companies secured the passage of the WTO Agreement on Trade-Related Aspects of Intellectual Property Rights (TRIPs), even though for many countries other than the United States, this imposed high costs with regard to producing generic, as opposed to patented, medicines. However, by analytically assuming a horizontal plane, nodal theory helps avoid the depoliticizing conclusion to which this one-sided account might lead. Instead, it enables us to see that social movements can also form superstructural nodes. Thus, in the context of the campaign for affordable anti-retroviral drugs in South Africa, local activists formed such a node with various transnational development and health NGOs to mobilize a counter-TRIPs network to challenge the protected position of pharmaceutical companies against the manufacture of generic medicines. This example also shows that the most effective nodal resources come in the messy noninstitutional form of globalization from below as the coalition's efforts led to a significant reduction in the cost of HIV/AIDS treatment. ${ }^{122}$

This leads to a final, but vital, implication of constitutionalism from below, namely that we can, at the same time, acknowledge the complexity of governance in the context of globalization and theorize the latter's transformation. As such, social movements direct our attention to the more general blind spot within systems' theoretical approaches to law with regard to the relation between structure and agency, and how this produces social change. ${ }^{123}$ Here, Stammers suggests that adverting to social movements challenges the prevalent view that agency and structure necessarily stand in opposition to each other. ${ }^{124}$ Drawing on the work of Piotr Sztompka, he posits a more nuanced alternative, which sees agency as produced by both structures and (individual and collective) actors, and with this, "the capacity to influence actions and

121. See Clifford Shearing \& Jennifer Wood, Nodal Governance, Democracy and the New 'Denizens', 30 J.L. \& SoC'Y 400, 404 (2003).

122. See Heinz Klug, Campaigning for Life: Building a New Transnational Solidarity in the Face of HIV/AIDS and TRIPS, in LAW AND GLOBALIZATION FROM BELOW: TOWARDS A COSMOPOLITAN LEGALITY, supra note 16, at 118-19.

123. See SANTOS, supra note 40 , at $58-59$.

124. See STAMMERS, supra note 11, at 25.27. 
outcomes."125 Stammers suggests that this fits better with the more fluid "creative praxis" of social movements: not only are the latter often catalysts for social transformation against apparently over determining structures, but to the extent their endeavors are directed to changing these structures, they can be seen to generate more than simply discrete acts of resistance. On this understanding of social change, social movements are ideally placed "to straddle the porous boundaries between institutional and everyday worlds." 126 Furthermore, this would seem to counter the argument that social movements can never do more than reproduce the power relations of the institutional arrangements they seek to challenge, leading us to conceive of social struggle from below as a means of effecting "contingent progress through social transformation." 127 In these ways, constitutionalism from below seeks to transcend the limitations of institutional analysis.

\section{CONCLUSION}

Most theorists of constitutionalism beyond the state would likely agree with Neil Walker's reflection that by engaging with globalization, constitutional discourse opens itself to a meta level of analysis. ${ }^{128}$ In this regard, the meta prefix is generally understood to denote the relational character of constitutionalism, brought about by the proliferation of constitutional sites. Thus, much of the initial literature focused upon the interaction between state and emerging supranational constitutional sites; societal constitutionalism has added to, and enormously enriched, this body of work by extending the scope of analysis to include the constitutional relations generated in the transnational private sphere. However, such discussions always take place within the shadow of a further meta dimension, namely, because our current conception of constitutionalism is only meaningful in light of various antecedent separations. Much of the critical response to globalization from above thus far tracks a separation well documented in the national context between economics and politics. Here, we have sought to draw attention to a different separation, namely that between the institutional and the noninstitutional dimensions of constitutionalism. In the global age, this separation can no longer be obscured: accordingly, addressing the implication of constitutionalism from below becomes one of the central issues for the ensuing debates on the relation between globalization and constitutionalism.

125. Id. at 25 .

126. Id. at 36 .

127. Id. at 30 .

128. Walker, supra note 26 , at 36 . 